\title{
The prevalence and risk factors of overactive bladder symptoms and its relation to pelvic organ prolapse symptoms in a general female population
}

\author{
Tiny A. de Boer • Marijke C. P. Slieker-ten Hove • \\ Curt W. Burger • Mark E. Vierhout
}

Received: 12 August 2010 / Accepted: 4 November 2010 /Published online: 23 November 2010

(C) The Author(s) 2010. This article is published with open access at Springerlink.com

\begin{abstract}
Introduction and hypothesis To study the prevalence and risk factors of overactive bladder $(\mathrm{OAB})$ symptoms and its relationship with symptoms of pelvic organ prolapse (POP). Methods This is a cross-sectional study including women aged between 45 and 85 years, registered in eight general practices. All women were asked to self complete the validated Dutch translated questionnaires. All symptoms were dichotomized as present or absent based on responses to each symptom and degree of bother.

Results Forty-seven percent of the women filled out the questionnaire. Prevalence of urgency was $34 \%$ and the prevalence of any OAB symptoms $49 \%$. Prevalence of $\mathrm{OAB}$ symptoms increased with advancing age. Symptoms of POP were an independent risk factor for symptomatic $\mathrm{OAB}$. Other risk factors were continence and prolapse surgery in the past, age above 75 , overweight, postmenopausal status and smoking.

Conclusions The prevalence of any $\mathrm{OAB}$ symptoms was $49 \%$. POP symptoms were an independent risk factor for symptomatic $\mathrm{OAB}$.
\end{abstract}

Keywords Overactive bladder - Urgency · Urge incontinence . Frequency Pelvic organ prolapse .

Prevalence

T. A. de Boer $(\bowtie) \cdot$ M. E. Vierhout

Department of Obstetrics and Gynaecology,

Radboud University Nijmegen Medical Centre,

PO Box 9101, 6500 HB Nijmegen, The Netherlands

e-mail: T.deBoer@obgyn.umcn.nl

M. C. P. Slieker-ten Hove • C. W. Burger

Department of Obstetrics and Gynaecology,

Erasmus Medical Centre,

Rotterdam, The Netherlands

\section{Introduction}

Pelvic organ prolapse (POP) and overactive bladder (OAB) symptoms are important problems for women. POP is a prevalent problem which has been reported to affect $50 \%$ of parous women [1]. Eleven percent of the women will have undergone an operation for prolapse or urinary incontinence by the age of $80[2]$.

$\mathrm{OAB}$ is known to be a highly prevalent disorder that increases with age in both sexes and that has a profound impact on quality of life [3]. According to the International Continence Society (ICS) OAB is defined as urgency with or without urge incontinence, usually with frequency and nocturia [4]. This term can only be used if there is no proven infection or 'obvious pathology'. It is a matter of debate whether POP should be considered as 'obvious pathology'.

Symptoms of OAB are often seen in patients with POP [5]. Community based studies showed that the prevalence of $\mathrm{OAB}$ symptoms is higher in patients with POP than without POP [5]. The same tendency is found in hospital based studies [5]. Nevertheless, the literature about the prevalence of the combination of POP and $\mathrm{OAB}$ is scarce.

To study the relation between POP and OAB, we used data from a cross-sectional study which was performed in a small Dutch city about the prevalence of pelvic floor symptoms in the general population [6].

The objective of this study is to investigate risk factors for $\mathrm{OAB}$ and specifically to explore the relationship between $\mathrm{OAB}$ and prolapse. This is important for clinical practice because the two diagnoses are often co-occurring which has possible consequences for diagnosis and treatment. 


\section{Methods}

The study was cross-sectional in a small town, Brielle, in the Netherlands. Brielle was chosen because it has a homogenic population, where all women are registered in one of the nine general practices. All women aged 45 to 85 years registered on the patients lists of eight out of nine general practices were invited to enrol in the study, which is $95 \%$ of the women in this age group. The women were sent information about the study and informed that they could enrol by filling out an informed consent form. All women who consented were asked to complete a self-report questionnaire. Non-responders received a reminder 8 weeks later that contained the same questionnaire. To check for selection bias, permanent non-responders were invited to complete a short questionnaire that comprised five questions about age, parity, presence of stress urinary incontinence (yes/no), faecal incontinence (yes/no) and feeling of vaginal bulging (yes/no). To encourage a high response to the questionnaire, we used envelopes with the name and logo of the Erasmus University, coloured paper and stamped addressed return envelopes.

Three options were possible: women refused to participate in the study, women filled out only the questionnaire and women filled out the questionnaire and underwent vaginal examination. For the purpose of this study, data on vaginal examination are not used. The relation between symptoms and signs of vagina prolapse has been extensively described in an earlier study [6]. A flowchart of the study design is presented in Fig. 1. In this study, all women who answered the questionnaires are included.

The self-reported questionnaire used for this study are a composite of internationally well-known questionnaires that have been validated for the Dutch language. It contains, amongst others, disease-specific questions from the validated Dutch translation of the Urinary Distress Inventory(UDI) [7] next to other questionnaires and items which were not used for the present study [6].

Fig. 1 Flowchart of the study

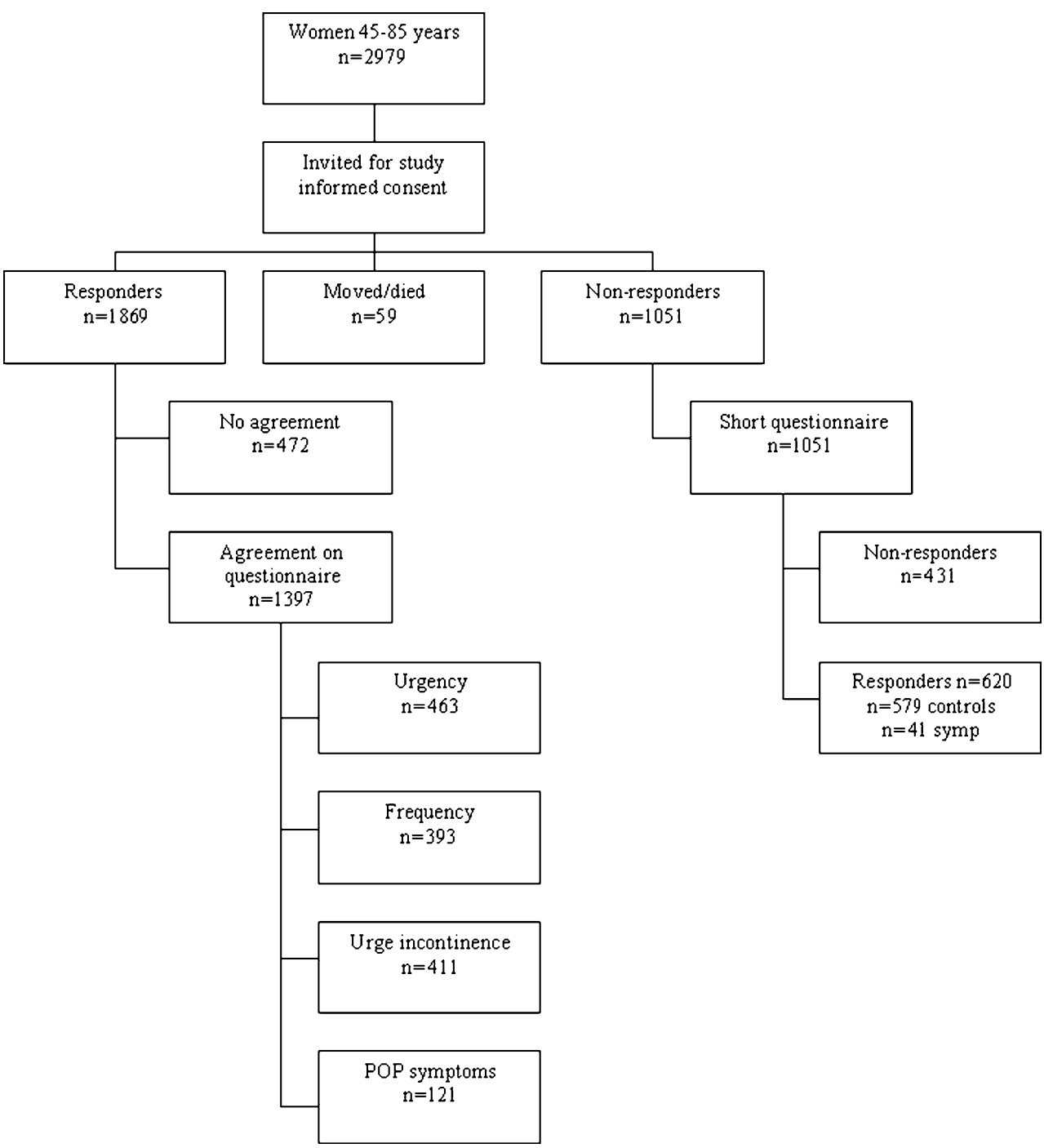


Women rated the amount of bother of various symptom on a 5-point Likert scale, from 0 (no complaints at all) to 4 (very serious complaints). In addition, questions about ethnicity, parity, POP symptoms during pregnancy, family history, menopausal status, hormone replacement therapy (HRT), previous pelvic floor surgery, educational level, smoking and heavy physical work were also included.

The Medical Ethics Research Committee (METC) of the Erasmus MC in Rotterdam, the Netherlands, approved this study.

\section{Measurements}

All symptoms were dichotomized as present or absent based on responses to each symptom and degree of bother with these symptoms. Women who denied the presence of a specific symptom as well as women who answered confirmative on a specific question but answered not to be bothered by it were considered as negative (absent) while women who indicated that they were little to severe bothered were considered as positive (present). The item of POP symptoms is merged from women who reported either seeing and/or feeling vaginal bulging. For the item any $\mathrm{OAB}$ symptoms, women who had urgency and/or frequency and/or urge incontinence symptoms were included (see Fig. 2).

Data are presented as number of women (percentage), mean (standard deviation) or median (range) as appropriate. Chi-square test was used to compare the difference between the women with- versus without POP symptoms.

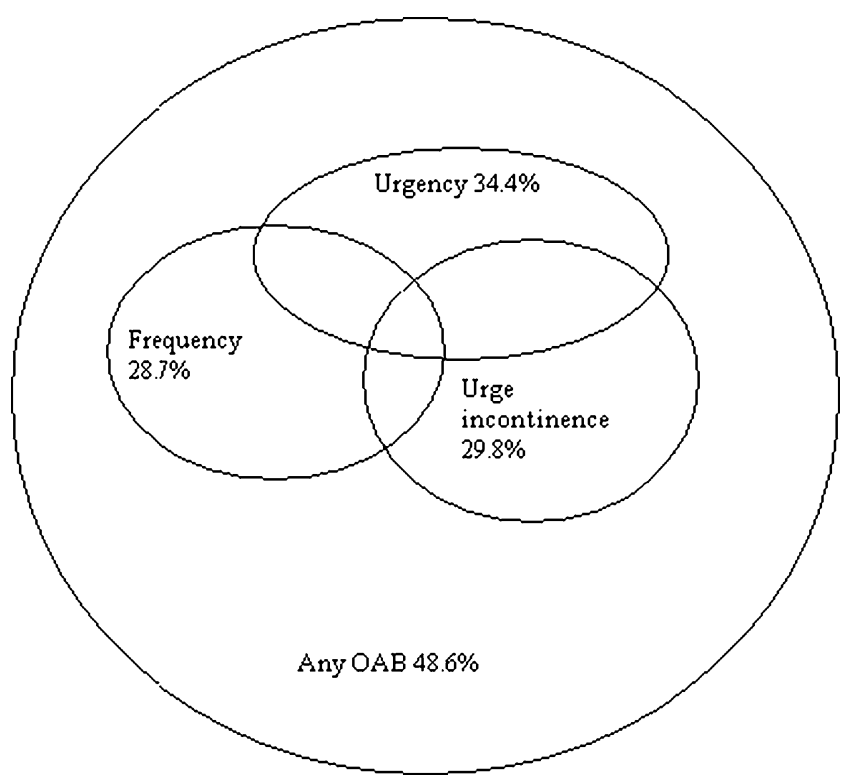

Fig. 2 Any $\mathrm{OAB}$ symptoms in relation to urgency, frequency and urge incontinence
Logistic regression was used for the univariate and multivariate analysis. For logistic regression, the backward elimination procedure was used. Variables with a $P<0.3$ in univariate analysis were included in the multivariate analysis. We presented the odds ratio (OR) and $95 \% \mathrm{CI}$ for each of the $\mathrm{OAB}$ symptoms. The level of significance was set at an alpha value of 0.05 . All data were entered and analysed in a SPSS 15.0 database for Windows (SPSS, Inc., Chicago, IL).

\section{Results}

Of the 2,979 women who were eligible for this study, 1,397 $(47 \%)$ filled out the questionnaire. In the non-responder group, $59 \%$ filled out and returned the short questionnaire (620/1,051), giving a total response rate of $62.7 \%$ (Fig. 1). Scores in the short questionnaire group were not significantly different from those in the total study group. Details of the response rate are presented in a previous report [6].

Table 1 shows the characteristics of the women included in this study. Table 2 shows the prevalence of $\mathrm{OAB}$ symptoms per age category. In Table 3, the prevalence of POP symptoms in women with and without OAB symptoms is presented.

In Table 4, the various possible risk factors including the presence of POP symptoms for the presence of OAB symptoms are presented in a univariate logistic regression model.

The OR shows the chance of the presence of OAB symptoms. An OR $>1$ indicates that the factor is positively correlated with the outcome variable; an $\mathrm{OR}<1$ means that the factor indicates a negative correlation.

Table 5 shows the multivariate analysis of the $\mathrm{OAB}$ symptoms where all factors of the univariate analysis with a $P<0.3$ are taken into account.

\section{Discussion}

In this cross-sectional study, we looked at the prevalence of $\mathrm{OAB}$ symptoms and specifically the relationship between OAB symptoms and POP symptoms. We found a prevalence of urgency, frequency and urge urinary incontinence of $34 \%, 29 \%$ and $30 \%$, respectively. The prevalence for any OAB symptoms was $49 \%$. This is comparable with other studies, where a prevalence of $16.8-49 \%$ was found in women [3, 8]. POP symptoms were present in $11.4 \%$, which is comparable with other studies where a prevalence of $4-30 \%$ was found [9-11].

\section{Risk factors}

This study found POP symptoms to be an independent risk factor for $\mathrm{OAB}$ symptoms. The sparse cross-sectional 
Table 1 Patients' characteristics and details of previous pelvic operations

\begin{tabular}{|c|c|}
\hline Number of women & 1397 \\
\hline \multicolumn{2}{|l|}{ Age (years) ${ }^{\mathrm{a}}$} \\
\hline $45-55$ & $647(46.9 \%)$ \\
\hline $56-65$ & $435(31.5 \%)$ \\
\hline $66-75$ & $233(16.9 \%)$ \\
\hline $76-85$ & $66(4.8 \%)$ \\
\hline \multicolumn{2}{|l|}{ Parity } \\
\hline 0 & $120(8.6 \%)$ \\
\hline 1 & $215(15.4 \%)$ \\
\hline 2 & $675(48.3 \%)$ \\
\hline$\geq 3$ & $387(27.7 \%)$ \\
\hline \multicolumn{2}{|l|}{ Body mass index $(\mathrm{kg} / \mathrm{m} 2)^{\mathrm{b}}$} \\
\hline$<20$ & $53(3.9 \%)$ \\
\hline $20-25$ & $599(43.9 \%)$ \\
\hline $25-30$ & $519(38.0 \%)$ \\
\hline$\geq 30$ & $193(14.1 \%)$ \\
\hline \multicolumn{2}{|l|}{ Race $^{c}$} \\
\hline Caucasian & $1,351(98.5 \%)$ \\
\hline Non-Caucasian & $20(1.5 \%)$ \\
\hline \multicolumn{2}{|l|}{ Smoking } \\
\hline Former smoking $^{\mathrm{d}}$ & $326(23.6 \%)$ \\
\hline Current smoking $^{\mathrm{d}}$ & $280(20.3 \%)$ \\
\hline Postmenopausal status & $1,009(72.2 \%)$ \\
\hline Hormone suppletion $^{\mathrm{e}}$ & $88(6.4 \%)$ \\
\hline \multicolumn{2}{|c|}{ Previous gynaecological surgery } \\
\hline Prolapse surgery ${ }^{\mathrm{h}}$ & $103(7.4 \%)$ \\
\hline Hysterectomy $^{\mathrm{i}}$ & $234(16.9 \%)$ \\
\hline Incontinence surgery ${ }^{\mathrm{j}}$ & $47(3.4 \%)$ \\
\hline
\end{tabular}

Data are presented as number of women (percentage)

${ }^{a}$ Data on 16 women are missing

${ }^{\mathrm{b}}$ Data on 33 women are missing

${ }^{\mathrm{c}}$ Data on 26 women are missing

${ }^{\mathrm{d}}$ Data on 15 women are missing

${ }^{\mathrm{e}}$ Data on 30 women are missing

${ }^{\mathrm{f}}$ Data on 25 women are missing

${ }^{\mathrm{g}}$ Data on 18 women are missing

${ }^{\mathrm{h}}$ Data on 13 women are missing

${ }^{\mathrm{i}}$ Data on 14 women are missing

${ }^{\mathrm{j}}$ Data on 15 women are missing

studies who mentioned a relationship between POP symptoms and $\mathrm{OAB}$, showed a higher prevalence of $\mathrm{OAB}$ symptoms with POP symptoms than without POP symptoms (!) [5] but were not controlled for other risk factors. The same relationship between POP and OAB is found in hospital based studies, the prevalence of OAB symptoms is greater in patients with POP than without POP [5]. However, by the nature of these epidemiological studies a
Table 2 Prevalence of overactive bladder symptoms and any OAB symptoms per age group ${ }^{\mathrm{a}}$

\begin{tabular}{lrrrr}
\hline & Frequency $^{\mathrm{b}}$ & Urgency $^{\mathrm{c}}$ & \multicolumn{2}{l}{$\begin{array}{l}\text { Urge } \\
\text { incontinence }\end{array}$} \\
& & $\begin{array}{l}\text { Any of the OAB } \\
\text { symptoms }\end{array}$ \\
\hline $45-55$ & $162(25.3 \%)$ & $193(30.9 \%)$ & $178(27.7 \%)$ & $298(46.1 \%)$ \\
$56-65$ & $121(28.4 \%)$ & $141(33.7 \%)$ & $116(26.9 \%)$ & $200(46.2 \%)$ \\
$66-75$ & $80(35.9 \%)$ & $92(40.5 \%)$ & $79(35.0 \%)$ & $126(54.5 \%)$ \\
$76-85$ & $24(37.5 \%)$ & $33(54.1 \%)$ & $32(48.5 \%)$ & $42(63.6 \%)$ \\
Overall & $393(28.7 \%)$ & $463(34.4 \%)$ & $411(29.8 \%)$ & $677(48.6 \%)$ \\
\hline
\end{tabular}

Data are presented as number of women (percentage)

${ }^{\text {a }}$ Data on age category on 16 women are missing

${ }^{\mathrm{b}}$ Data on frequency on 28 women are missing

${ }^{\mathrm{c}}$ Data on urgency on 52 women are missing

${ }^{\mathrm{d}}$ Data on urge incontinence on 16 women are missing

causal relationship cannot be established. There are many possible theories regarding the pathophysiology of $\mathrm{OAB}$ in relation to POP and it is likely that bladder obstruction plays an important role [5]. Nevertheless, several other mechanisms might be considered. The pathophysiological relationship between $\mathrm{OAB}$ and POP needs to be studied further. Important clinical implication of the relationship between POP and OAB is that treatment of POP could give an improvement in $\mathrm{OAB}$ symptoms. This is consistent with the finding in a recent review [5].

Another important risk factor for OAB symptoms was surgery for urinary incontinence in the past. Many studies have shown a relationship between continence surgery and $\mathrm{OAB}$ symptoms where the prevalence of de novo $\mathrm{OAB}$ varied between $15 \%$ and $29 \%$ on the short term (1-3 months postoperatively) $[12,13]$ and $0-30 \%$ on the long term [12-14]. As in other studies, we found

Table 3 Prevalence of prolapse symptoms ${ }^{\mathrm{e}}$ in women with symptoms of $\mathrm{OAB}$

\begin{tabular}{llll}
\hline & $\begin{array}{l}\text { Prolapse } \\
\text { symptoms }\end{array}$ & $\begin{array}{l}\text { No prolapse } \\
\text { symptoms }\end{array}$ & $P^{\mathrm{a}}$ \\
\hline Frequency $^{\mathrm{b}}$ & $66(41.8 \%)$ & $320(26.9 \%)$ & 0.000 \\
Urgency $^{\mathrm{c}}$ & $77(49.7 \%)$ & $379(32.4 \%)$ & 0.000 \\
Urge incontinence $^{\mathrm{d}}$ & $64(40.3 \%)$ & $340(28.3 \%)$ & 0.003 \\
$\begin{array}{l}\text { Any of the OAB } \\
\text { symptoms }\end{array}$ & $84(69.4 \%)$ & $588(46.6 \%)$ & 0.000 \\
\hline
\end{tabular}

Data are presented as number of women (percentage)

${ }^{a} P$ value using chi-square test to compare the difference between women with versus without prolapse symptoms.

${ }^{\mathrm{b}}$ Data on 28 women are missing

${ }^{\mathrm{c}}$ Data on 52 women are missing

${ }^{\mathrm{d}}$ Data on 16 women are missing

${ }^{\mathrm{e}}$ Data on four women are missing

${ }^{\mathrm{f}}$ Data on prolapse symptoms on 24 women are missing 
Table 4 Factors of the univariate logistic regression analysis on the various OAB symptoms

\begin{tabular}{|c|c|c|c|c|c|}
\hline & & $\begin{array}{l}\text { Frequency OR } \\
(95 \% \mathrm{CI})\end{array}$ & $\begin{array}{l}\text { Urgency OR } \\
(95 \% \mathrm{CI})\end{array}$ & $\begin{array}{l}\text { Urge incontinence OR } \\
(95 \% \mathrm{CI})\end{array}$ & $\begin{array}{l}\text { Any OAB OR } \\
(95 \% \mathrm{CI})\end{array}$ \\
\hline \multirow[t]{4}{*}{ Age (years) ${ }^{\mathrm{a}}$} & $45-55$ & Ref & Ref & Ref & Ref \\
\hline & $56-65$ & $1.2(0.9,1.5)$ & $1.1(0.9,1.5)$ & $1.0(0.7,1.3)$ & $1.0(0.8,1.3)$ \\
\hline & $66-75$ & $1.7(1.2,2.3)$ & $1.5(1.1,2.1)$ & $1.4(1.0,1.9)$ & $1.4(1.0,1.9)$ \\
\hline & $76-85$ & $1.8(1.0,3.0)$ & $2.6(1.5,4.5)$ & $2.5(1.5,4.1)$ & $2.0(1.2,3.5)$ \\
\hline \multirow[t]{2}{*}{ Parity } & $\leq 2$ & Ref & Ref & Ref & Ref \\
\hline & $>2$ & $1.3(1.0,1.7)$ & $1.0(0.8,1.3)$ & $1.0(0.8,1.3)$ & $1.2(0.9,1.5)$ \\
\hline \multirow[t]{4}{*}{ Body mass index $(\mathrm{kg} / \mathrm{m} 2)^{\mathrm{b}}$} & $<20$ & $0.7(0.3,1.5)$ & $0.4(0.2,1.0)$ & $0.7(0.4,1.5)$ & $0.6(0.3,1.0)$ \\
\hline & $20-25$ & Ref & Ref & Ref & Ref \\
\hline & $25-30$ & $1.6(1.3,2.1)$ & $1.3(1.0,1.7)$ & $1.5(1.1,1.9)$ & $1.4(1.1,1.7)$ \\
\hline & $\geq 30$ & $2.0(1.4,2.8)$ & $2.2(1.6,3.1)$ & $2.2(1.6,3.1)$ & $2.3(1.7,3.2)$ \\
\hline \multicolumn{6}{|l|}{ Smoking } \\
\hline \multirow[t]{2}{*}{ Former smoking ${ }^{\mathrm{c}}$} & Yes & $1.3(1.0,1.8)$ & $1.2(0.9,1.6)$ & $1.0(0.8,1.4)$ & $1.1(0.8,1.4)$ \\
\hline & No & Ref & Ref & Ref & Ref \\
\hline \multirow[t]{2}{*}{ Current smoking $^{\mathrm{c}}$} & Yes & $1.0(0.8,1.4)$ & $1.3(1.0,1.7)$ & $1.3(1.0,1.7)$ & $1.2(1.0,1.6)$ \\
\hline & No & Ref & Ref & Ref & Ref \\
\hline \multirow[t]{2}{*}{ Postmenopausal status } & Yes & $1.5(1.2,2.0)$ & $1.6(1.2,2.0)$ & $1.4(1.1,1.8)$ & $1.3(1.0,1.7)$ \\
\hline & No & Ref & Ref & Ref & Ref \\
\hline \multirow[t]{2}{*}{ Hormonal suppletion therapy ${ }^{\mathrm{e}}$} & Yes & $1.2(0.7,1.9)$ & $1.2(0.7,1.8)$ & $0.7(0.4,1.2)$ & $0.9(0.6,1.4)$ \\
\hline & No & Ref & Ref & Ref & Ref \\
\hline \multicolumn{6}{|l|}{ Previous gynaecological surgery } \\
\hline \multirow[t]{2}{*}{ Prolapse surgery ${ }^{\mathrm{d}}$} & Yes & $2.5(1.7,3.8)$ & $2.6(1.7,3.9)$ & $1.9(1.3,2.9)$ & $2.9(1.9,4.6)$ \\
\hline & No & Ref & Ref & Ref & Ref \\
\hline \multirow[t]{2}{*}{ Hysterectomy ${ }^{\mathrm{h}}$} & Yes & $1.5(1.1,2.1)$ & $1.3(0.9,1.7)$ & $1.3(1.0,1.8)$ & $1.3(1.0,1.7)$ \\
\hline & No & Ref & Ref & Ref & Ref \\
\hline \multirow[t]{2}{*}{ Incontinence surgery $^{c}$} & Yes & $3.5(1.9,6.5)$ & $3.4(1.9,6.3)$ & $4.3(2.3,8.0)$ & $6.5(2.9,14.5)$ \\
\hline & No & Ref & Ref & Ref & Ref \\
\hline \multirow[t]{2}{*}{ Prolapse symptoms ${ }^{\mathrm{i}}$} & Yes & $2.0(1.4,2.7)$ & $2.1(1.5,2.9)$ & $1.7(1.2,2.4)$ & $2.6(1.7,3.9)$ \\
\hline & No & Ref & Ref & Ref & Ref \\
\hline
\end{tabular}

All values with $P<0.05$ are illustrated in bold

Ref: reference

${ }^{\mathrm{a}}$ Data on 16 women are missing

${ }^{\mathrm{b}}$ Data on 33 women are missing

${ }^{\mathrm{c}}$ Data on 15 women are missing

${ }^{\mathrm{d}}$ Data on 13 women are missing

${ }^{\mathrm{e}}$ Data on 30 women are missing

${ }^{\mathrm{f}}$ Data on 25 women are missing

${ }^{\mathrm{g}}$ Data on 18 women are missing

${ }^{\mathrm{h}}$ Data on 14 women are missing

${ }^{\mathrm{i}}$ Data on 24 women are missing

the prevalence of $\mathrm{OAB}$ symptoms increased with advancing age $[3,8]$.

Overweight (body mass index [BMI] greater then 30) was another independent risk factor for $\mathrm{OAB}$ symptoms. This is consistent with other studies, who found the same relationship [15-19]. The study of Cheung found a similar OR for overweight [15], where the study of Lawrence found a higher OR (2.73) [18]. On the other hand, Choo et al. [16] found that BMI was only a predictor for OAB dry (urgency with or without frequency or nocturia), but not for $\mathrm{OAB}$ wet (urgency with urge incontinence, with or without frequency or nocturia).

Another factor for achieving urgency was smoking. Other studies are not conclusive about the role of smoking in OAB [17, 20, 21]. The study of Bradley et al. [20] found no relation between current smoking and urinary symp- 
Table 5 Risk factors on $\mathrm{OAB}$ symptoms after multivariate regression analysis

\begin{tabular}{|c|c|c|c|c|c|}
\hline & & $\begin{array}{l}\text { Frequency OR } \\
(95 \% \text { CI })\end{array}$ & $\begin{array}{l}\text { Urgency OR } \\
(95 \% \mathrm{CI})\end{array}$ & $\begin{array}{l}\text { Urge incontinence OR } \\
(95 \% \mathrm{CI})\end{array}$ & $\begin{array}{l}\text { Any OAB OR } \\
(95 \% \mathrm{CI})\end{array}$ \\
\hline \multirow[t]{4}{*}{ Age $(\text { years })^{\mathrm{a}}$} & $45-55$ & & Ref & Ref & Ref \\
\hline & $56-65$ & & $1.0(0.8,1.4)$ & $0.9(0.6,1.1)$ & $0.9(0.7,1.2)$ \\
\hline & $66-75$ & & $1.4(1.0,2.0)$ & $1.3(0.9,1.8)$ & $1.3(1.0,1.8)$ \\
\hline & $76-85$ & & $2.7(1.5,4.9)$ & $2.2(1.3,3.8)$ & $2.1(1.2,3.7)$ \\
\hline \multirow[t]{4}{*}{ Body mass index $\left(\mathrm{kg} / \mathrm{m}^{2}\right)^{\mathrm{b}}$} & $<20$ & $0.7(0.3,1.6)$ & $0.4(0.2,0.9)$ & $0.7(0.3,1.5)$ & $0.5(0.3,1.0)$ \\
\hline & $20-25$ & Ref & Ref & Ref & Ref \\
\hline & $25-30$ & $1.5(1.1,2.0)$ & $1.2(0.9,1.6)$ & $1.3(1.0,1.8)$ & $1.3(1.0,1.6)$ \\
\hline & $\geq 30$ & $1.7(1.2,2.4)$ & $2.2(1.5,3.1)$ & $2.0(1.4,2.9)$ & $2.2((1.5,3.1)$ \\
\hline \multicolumn{6}{|l|}{ Smoking } \\
\hline \multirow[t]{2}{*}{ Smoking in the past ${ }^{\mathrm{c}}$} & Yes & & $1.4(1.1,1.9)$ & & \\
\hline & No & & Ref & & \\
\hline \multirow[t]{2}{*}{ Current smoking $^{\mathrm{c}}$} & Yes & & $1.7(1.2,2.3)$ & & $1.4(1.0,1.8)$ \\
\hline & No & & Ref & & Ref \\
\hline \multirow[t]{2}{*}{ Postmenopausal status } & Yes & $1.3(1.0,1.8)$ & & & \\
\hline & No & Ref & & & \\
\hline \multicolumn{6}{|l|}{ Previous gynaecological surgery } \\
\hline \multirow[t]{2}{*}{ Prolapse surgery ${ }^{\mathrm{d}}$} & Yes & & $2.3(1.4,3.6)$ & & \\
\hline & No & & Ref & & \\
\hline \multirow[t]{2}{*}{ Incontinence surgery ${ }^{\mathrm{e}}$} & Yes & $2.9(1.5,5.5)$ & & $4.3(2.3,8.2)$ & $6.7(2.8,16.3)$ \\
\hline & No & Ref & & Ref & Ref \\
\hline \multirow[t]{2}{*}{ Prolapse symptoms ${ }^{\mathrm{f}}$} & Yes & $2.4(1.6,3.5)$ & $2.2(1.4,3.3)$ & $1.8(1.2,2.6)$ & $2.3(1.5,3.5)$ \\
\hline & No & Ref & Ref & Ref & Ref \\
\hline Variance explained by the model ${ }^{\mathrm{g}}$ & & $5.8 \%$ & $8.8 \%$ & $6.6 \%$ & $9.1 \%$ \\
\hline
\end{tabular}

$O R$ odds rario, Ref reference

${ }^{\mathrm{a}}$ Data on 16 women are missing

${ }^{\mathrm{b}}$ Data on 33 women are missing

${ }^{\mathrm{c}}$ Data on 15 women are missing

${ }^{\mathrm{d}}$ Data on 13 women are missing

${ }^{\mathrm{e}}$ Data on 18 women are missing

${ }^{\mathrm{f}}$ Data on 24 women are missing

${ }^{\mathrm{g}}$ Nagelkerke $R^{2}$

toms, while a large cross-sectional study showed that current and former smoking was associated with urgency [21]. One study found that current smokers were 1.44 time more likely to develop $\mathrm{OAB}$, and the increased risk for former smokers was nearly significant [17]. The induction of OAB in smoking could be related to an anti-oestrogenic hormonal effect on the bladder and uretra [22] and a nicotine induced phasic contraction of the detrusor muscle [23].

Postmenopausal status was a risk factor for the symptom frequency in our study. This is consistent with another study which found postmenopausal status to be a predictor for OAB symptoms [24]. This can be explained because oestrogen has an important role in the urogenital tract through oestrogen receptors in urethra, bladder and pelvic floor [25], where deficiency causes atrophic changes [26], which is associated with
OAB symptoms. Reversal of the atrophy by oestrogen treatment can have a positive influence on OAB symptoms [27].

Surprisingly, we found previous prolapse surgery to be a predictor for the symptom urgency, this in contrast to practically all studies that showed an improvement of OAB symptoms after prolapse surgery [5]. A possible explanation for this finding is that women after prolapse surgery achieved de novo urgency, as was found in $5 \%$ of the patients in one study [28].

\section{Strengths and weaknesses}

The strong point about this study is that it is a large crosssectional study in a homogenic female population, which made multivariate analysis possible; as a result, however, 
genetic and racial factors could not be included, which is also an inherent weakness of the design.

Another weakness of this study is that not all factors of influence on $\mathrm{OAB}$ are included, such as food and beverages (coffee and alcoholic consumption) and the use of $\mathrm{OAB}$ therapies (bladder training and pharmacotherapy).

\section{Conclusion}

In this study, we found a prevalence of urgency of $34 \%$, as the core symptom of the $\mathrm{OAB}$ spectrum, and of any $\mathrm{OAB}$ symptoms of $49 \%$. POP symptoms are an independent risk factor for OAB symptoms. Other risk factors are continence surgery in the past, age above 75 , overweight and smoking.

\section{Conflicts of interest None.}

Open Access This article is distributed under the terms of the Creative Commons Attribution Noncommercial License which permits any noncommercial use, distribution, and reproduction in any medium, provided the original author(s) and source are credited.

\section{References}

1. Digesu GA, Chaliha C, Salvatore S, Hutchings A, Khullar V (2005) The relationship of vaginal prolapse severity to symptoms and quality of life. BJOG 112(7):971-976

2. Olsen AL, Smith VJ, Bergstrom JO, Colling JC, Clark AL (1997) Epidemiology of surgically managed pelvic organ prolapse and urinary incontinence. Obstet Gynecol 89(4):501-506

3. Temml C, Heidler S, Ponholzer A, Madersbacher S (2005) Prevalence of the overactive bladder syndrome by applying the International Continence Society definition. Eur Urol 48(4):622-627

4. Abrams P, Cardozo L, Fall M, Griffiths D, Rosier P, Ulmsten U, van KP, Victor A, Wein A (2002) The standardisation of terminology of lower urinary tract function: report from the Standardisation Sub-committee of the International Continence Society. Neurourol Urodyn 21(2):167-178

5. de Boer TA, Salvatore S, Cardozo L, Chapple C, Kelleher C, van Kerrebroeck P, Kirby MG, Koelbl H, Espuna-Pons M, Milsom I, Tubaro A, Wagg A, Vierhout ME (2010) Pelvic organ prolapse and overactive bladder. Neurourol Urodyn 29(1):30-39

6. Slieker-ten Hove MC, Pool-Goudzwaard AL, Eijkemans MJ, Steegers-Theunissen RP, Burger CW, Vierhout ME (2009) Symptomatic pelvic organ prolapse and possible risk factors in a general population. Am J Obstet Gynecol 200(2):184-187

7. Uebersax JS, Wyman JF, Shumaker SA, McClish DK, Fantl JA (1995) Short forms to assess life quality and symptom distress for urinary incontinence in women: the Incontinence Impact Questionnaire and the Urogenital Distress Inventory. Continence Program for Women Research Group. Neurourol Urodyn 14(2):131-139

8. Lapitan MC, Chye PL (2001) The epidemiology of overactive bladder among females in Asia: a questionnaire survey. Int Urogynecol J Pelvic Floor Dysfunct 12(4):226-231

9. Bump RC, Norton PA (1998) Epidemiology and natural history of pelvic floor dysfunction. Obstet Gynecol Clin North Am 25 (4):723-746
10. Eva UF, Gun W, Preben K (2003) Prevalence of urinary and fecal incontinence and symptoms of genital prolapse in women. Acta Obstet Gynecol Scand 82(3):280-286

11. Samuelsson EC, Victor FT, Tibblin G, Svardsudd KF (1999) Signs of genital prolapse in a Swedish population of women 20 to 59 years of age and possible related factors. Am J Obstet Gynecol 180(2 Pt 1):299-305

12. Abouassaly R, Steinberg JR, Lemieux M, Marois C, Gilchrist LI, Bourque JL, Tu IM, Corcos J (2004) Complications of tensionfree vaginal tape surgery: a multi-institutional review. BJU Int 94 (1):110-113

13. Tellez Martinez-Fornes M, Fernandez PC, Fouz LC, Fernandez LC, Borrego HJ (2009) A three year follow-up of a prospective open randomized trial to compare tension-free vaginal tape with Burch colposuspension for treatment of female stress urinary incontinence. Actas Urol Esp 33(10):1088-1096

14. Holmgren C, Nilsson S, Lanner L, Hellberg D (2007) Frequency of de novo urgency in 463 women who had undergone the tension-free vaginal tape (TVT) procedure for genuine stress urinary incontinence-a long-term follow-up. Eur J Obstet Gynecol Reprod Biol 132(1):121-125

15. Cheung WW, Khan NH, Choi KK, Bluth MH, Vincent MT (2009) Prevalence, evaluation and management of overactive bladder in primary care. BMC Fam Pract 10:8

16. Choo MS, Ku JH, Lee JB, Lee DH, Kim JC, Kim HJ, Lee JJ, Park WH (2007) Cross-cultural differences for adapting overactive bladder symptoms: results of an epidemiologic survey in Korea. World J Urol 25(5):505-511

17. Dallosso HM, McGrother CW, Matthews RJ, Donaldson MM (2003) The association of diet and other lifestyle factors with overactive bladder and stress incontinence: a longitudinal study in women. BJU Int 92(1):69-77

18. Lawrence JM, Lukacz ES, Nager CW, Hsu JW, Luber KM (2008) Prevalence and co-occurrence of pelvic floor disorders in community-dwelling women. Obstet Gynecol 111(3):678685

19. Teleman PM, Lidfeldt J, Nerbrand C, Samsioe G, Mattiasson A (2004) Overactive bladder: prevalence, risk factors and relation to stress incontinence in middle-aged women. BJOG 111(6):600 604

20. Bradley CS, Kennedy CM, Nygaard IE (2005) Pelvic floor symptoms and lifestyle factors in older women. J Womens Health (Larchmt) 14(2):128-136

21. Nuotio M, Jylha M, Koivisto AM, Tammela TL (2001) Association of smoking with urgency in older people. Eur Urol 40(2):206-212

22. Baron JA (1984) Smoking and estrogen-related disease. Am J Epidemiol 119(1):9-22

23. Hisayama T, Shinkai M, Takayanagi I, Toyoda T (1988) Mechanism of action of nicotine in isolated urinary bladder of guinea-pig. Br J Pharmacol 95(2):465-472

24. Zhang W, Song Y, He X, Huang H, Xu B, Song J (2006) Prevalence and risk factors of overactive bladder syndrome in Fuzhou Chinese women. Neurourol Urodyn 25(7):717-721

25. Iosif CS, Batra S, Ek A, Astedt B (1981) Estrogen receptors in the human female lower uninary tract. Am J Obstet Gynecol 141 (7):817-820

26. Versi E, Harvey MA, Cardozo L, Brincat M, Studd JW (2001) Urogenital prolapse and atrophy at menopause: a prevalence study. Int Urogynecol J Pelvic Floor Dysfunct 12(2):107-110

27. Robinson D, Cardozo L (2010) New drug treatments for urinary incontinence. Maturitas 65(4):340-347

28. de Boer TA, Kluivers KB, Withagen MI, Milani AL, Vierhout ME (2010) Predictive factors for overactive bladder symptoms after pelvic organ prolapse surgery. Int Urogynecol J Pelvic Floor Dysfunct 21(9):1143-1149 